\title{
Flowering Synchronization in Some Sugarcane Genotypes at Various Planting Dates under Natural Environment
}

\author{
Mohamed A. Ghonema ${ }^{1}$
}

\begin{abstract}
Flowering is essential in any breeding programme, particularly in genetic introgression programmes in which flowering synchronism is required. Due to changing weather conditions, the flowering vary in different planting dates with different conditions. In this work, sixteen sugarcane genotypes from different countries were tested for flowering under natural environment of Sabahia Research Station, Alexandria, Egypt in different planting seasons viz: Autumn 30 October 2013/14/15 (plant cane) \& 30 June 2015/16 (first ratoon) and Spring 30 March 2014/15 (plant cane) \& 30 April 2015/16 (first ratoon) at El-Sabahia Research Station (31 $\left.{ }^{\circ} 12^{\prime} \mathrm{N}\right)$, Alexandria, Egypt. It was observed that latitude, mean minimum and maximum temperature and length of day during flowering inductive phase (September and October) were within acceptable limits to favour the flowering in sugarcane. However, flowering occurred in most of the cane genotypes under natural environment in autumn and spring seasons in both plant cane and first ratoon, but the time and percentage of flowered genotypes differed between them. Data revealed that there were some genotypes that have the same full flowering date within each planting season, moreover some genotypes which had different dates of full flowering in the same planting season had the same date with each other in another different seasons in plant cane crop. That means two or more genotypes can be synchronized in two different planting seasons. Those genotypes which synchronized with each other can be easily crossed. In general, the early stages of flowering in sugarcane germplasm under study commenced from November, but full flowering began during the month of December. In the present study, some genotypes differed in the flowering dates in each planting season. It's possible to make crossing between certain genotypes efficiently by manipulating the dates of planting.
\end{abstract}

Key words: Sugarcane, Flowering, Synchronization, Genotypes, Planting dates.

\section{INTRODUCTION}

Sugarcane is a short day plant and it produces flowers at some locations in the world like Coimbatore (India), Barbados (West Indies), Canal point, Florida and Louisiana (USA), Taiwan, Natal (South Africa), Java (Indonesia), Brisbane (Australia) according to Moore and Nuss, 1987. Sugarcane breeders have found difficulties in synchronizing flowering in specific crosses. Flowering in sugarcane is affected by many factors like temperature, photoperiod, humidity, altitude and latitude. Self-pollination does occur in sugarcane and seed set mostly with cross-pollination (McIntyre and Jackson, 2001). Optimum photoperiod for flower induction is 12 hours and $35 \mathrm{~min}$ and flowering decline with any decrease in day length by $\pm 5 \mathrm{~min}$ (Coleman, 1959). At night period of 11 hours $32 \mathrm{~min}$ is very conducive for flowering (Clements and Awada, 1964). Flowering is inhibited where night temperature drops below $18^{\circ} \mathrm{C}$ (Coleman, 1963). Ten continuous nights with temperature below $18^{\circ} \mathrm{C}$ prevent flowering induction (Coleman, 1968). The extent that flowering is decreased depends on the clone, age of the crop, and availability of water. Araldi et al. (2010) reported that the factors that influence flowering are the sensitivity of the variety to flowering besides age of the plant (varieties that are very sensitive to flowering may be induced at six months). There are several factors affecting flowering including photoperiod, temperature, moisture, age and nutrition. One of the most important factors for flowering is photoperiod (Donna Glassop et al., 2014). Ahmed and Gardezi (2017) concluded that most germplasm need to be evaluated for flowering response with viable fuzz production to identify the best parents for future hybridization program.

Alexandria, Egypt, typifies the conditions of temperature and humidity ideal for floral induction. The optimum nycte period of 11:30 to 12:00 hours occurs from the last week of September to mid-October (Rao et al., 1973). For successful crossing, those genotypes which are known to flower at the same time must be selected. It is well known that sugarcane varieties can be classified as early to intermediate to late flowering. Under Egyptian conditions, the varieties varied from early flowering at the second week of January to late flowering at the second week of March (Rao et al., 1973). For crossing the late flowering varieties with the earlier flowering ones, the flowering dates must be modified by different treatments as controlled photoperiod (James, 1972). Other authors reported modification of flowering through spraying some chemicals or changing the planting dates. Vijayasaradhy and Narasimhan (1954); Coleman (1959); Daniels (1962) and George and Lalauette (1962) reported that age of cane, temperature, soil moisture, and fertility at the time of inductive day lengths interacted with the photoperiod to enhance, retard or prevent transformation

${ }^{1}$ Genetic and Breeding Department, Sugar Crops Research Institute, Agriculture Research Center, Egypt

Received May 7, 2017, Accepted May 31, 2017 
of the sugarcane apices from vegetative to reproductive growth.

The present study was carried out on sixteen sugar cane genotypes to assess their flowering behavior when planted at different seasons, to facilitate hybridization between synchronized genotypes at full flowering time.

\section{MATERIALS AND METHODS}

Experiments were conducted to observe flowering behavior of sugarcane germplasm under natural environment. Sixteen (16) genotypes of sugar cane from different countries were used in this study (Table 1). The genotypes were planted at different dates, namely: Autumn 30 October 2013/14/15 (plant cane) \& 30 June 2015/16 (first ratoon) and Spring 30 March/2014/15 (plant cane) \& 30 April 2015/16 (first ratoon). The experiment was carried out at El-Sabahia Research Station ( $\left.31^{\circ} 12^{`} \mathrm{~N}\right)$, Alexandria, Egypt. The clones were planted in 4 meter row length and $1.25 \mathrm{~m}$ apart. Low rates of nitrogen were applied 2-3 months after planting. Irrigation was carried out every 12 days intervals, except in August and September, where it was applied at 4 days intervals. All the other cultural practices were carried out as recommended. The different flowering stages were daily recorded and the date of every stage was noted from the first of October for all studied genotypes. The number of flowering stalks and the total number of stalks (tillers) per four meters row of each genotype was counted to calculate flowering intensity. Flowering intensity for each flowering genotype was expressed as percentage of flowered stalks out of the total number of stalks of each genotype. Daily mean minimum and maximum temperature, relative humidity and day length were recorded during the induction and flowering development period.

During the induction period, from the first fortnight of October to beginning of inflorescence development, the morphological changes that indicate flowering were recorded, such as elongation and the first formation date of each one from the four stages under study; 1(Development stage) beginning of inflorescence development; 2- (Flag stage) stopping formation of new leaves and beginning of the flag leaf formation and emergence; 3- (Tip stage) emergence of the inflorescence from flag leaf sheath; 4- (Full stage) full extension completed. All stages were calculated based on number of days from planting dates until the beginning of each stage.

The experimental was set up in split-plot design with three replicates. Observations were recorded at the four studied stages. The statistical analysis was performed using the CoStat program version 6.303 and means were compared using LSD at 5\% level of probability.

\section{RERSULTS AND DISCUSSION}

Results presented in Tables (2 and 3) shows different planting seasons and different flowering stages for sixteen genotypes, significant difference could be observed between the mean values of the four studied stages; development, flag, tip and full emergence. The period of floral initiation stage had the longest time when calculated from the first fortnight of October to beginning of inflorescence development. Also, there were significant differences between the genotypes for the date of the four stages, as well as the interaction between genotypes and different stages. In the present study, data in Table (2) showed the dates of different flowering stages of the plant cane genotypes in two seasons. Autumn planting at full flowering stage ranged from 414 to 548.33 days (December to May), however date of spring planting differed from 252.33 to 352 days (December to March). On the other hand, data in Table (3) illustrated that first ratoon autumn planting ranged from 262.33 to 440.33 days (March to September) and first ratoon spring planting differed from 227.67 to 288.33 days (December to February) up to the full flowering stage for the different genotypes. The flowering delay in first ratoon at autumn planting from (March to September) may be due to the cane did not reach the required age at induction period.

These results are in agreement with those obtained by Gosnell (1973) who found that varieties may differ slightly in their minimum age requirement before the "ripeness to flower" condition is fulfilled.

Table 1. Source country of sugarcane genotypes studied

\begin{tabular}{lccccc}
\hline No. & Genotype & Source & No. & Genotype & Source \\
\hline 1 & GT 54-9 & Giza, Egypt, Taiwan & 9 & BO 41-227 & Bihar, Orissa, India \\
2 & G2003-47 & Giza, Egypt & 10 & B 36-21 & Barbados \\
3 & G 2004-27 & Giza, Egypt & 11 & EH 26-2 & Hawamdia, Egypt \\
4 & G 2005-47 & Giza, Egypt & 12 & EI 37-10 & El-Salvador \\
5 & G 2006-3 & Giza, Egypt & 13 & IK 76-79 & Kalimantan, Indonesia \\
6 & BO 3 & Bihar, Orissa, India & 14 & N 11 & Natal, South Africa \\
7 & BO 19 & Bihar, Orissa, India & 15 & $82 / 4-21$ & Hawamdia, Egypt \\
8 & BO 22 & Bihar, Orissa, India & 16 & $85 / 3-35$ & Hawamdia, Egypt \\
\hline
\end{tabular}


Table 2. Days to flowering stages in some sugarcane genotypes (plant cane) in different planting seasons

\begin{tabular}{|c|c|c|c|c|c|c|c|c|c|c|}
\hline \multirow{3}{*}{ Genotype } & \multicolumn{4}{|c|}{ Autumn plant cane } & \multirow{3}{*}{$\begin{array}{l}\text { Genot. } \\
\text { Mean }\end{array}$} & \multicolumn{4}{|c|}{ Spring plant cane } & \multirow{3}{*}{$\begin{array}{l}\text { Genot. } \\
\text { Mean }\end{array}$} \\
\hline & \multicolumn{4}{|c|}{$2013 / 14 / 15$} & & & 2014 & $/ 15$ & & \\
\hline & Develop. & Flag & Tip & Full & & Develop. & Flag & Tip & Full & \\
\hline GT 54-9 & 467.00 & 474.00 & 481.33 & 489.00 & $477.83 b$ & 314.33 & 326.67 & 340.33 & 351.67 & $333.25 b$ \\
\hline G2003-47 & 0.00 & 0.00 & 0.00 & 0.00 & 0.00 & 270.67 & 290.33 & 304.67 & 316.33 & $295.50 \mathrm{~d}$ \\
\hline G 2004-27 & 422.00 & 430.00 & 442.33 & 455.67 & $437.50 \mathrm{c}$ & 260.67 & 290.33 & 314.67 & 322.67 & $297.08 d$ \\
\hline G 2005-47 & 592.33 & - & - & - & - & 259.67 & - & - & - & - \\
\hline G 2006-3 & 449.67 & 484.67 & 495.33 & 502.67 & $483.08 \mathrm{~b}$ & 240.00 & 258.67 & 294.67 & 308.67 & $275.50 \mathrm{e}$ \\
\hline BO 3 & 415.33 & 450.00 & - & - & - & 215.67 & 230.33 & 247.33 & 257.67 & $237.75 f$ \\
\hline BO 19 & 391.00 & 412.67 & 435.33 & 450.67 & $422.42 d$ & 346.00 & - & - & - & - \\
\hline BO 22 & 535.67 & 569.00 & - & - & - & 280.33 & 296.67 & 315.33 & 325.67 & $304.50 \mathrm{c}$ \\
\hline BO 41-227 & 402.67 & 422.33 & 451.33 & 455.67 & $433.00 \mathrm{c}$ & 319.67 & 334.67 & 346.67 & 352.00 & $338.25 \mathrm{a}$ \\
\hline B $36-21$ & 371.33 & 384.67 & 402.33 & 414.00 & $393.08 \mathrm{e}$ & 207.33 & 224.67 & 240.33 & 252.33 & $231.17 \mathrm{~g}$ \\
\hline EH 26-2 & 415.67 & 421.67 & 441.67 & 450.67 & $432.42 d$ & 0.00 & 0.00 & 0.00 & 0.00 & $0.00^{\circ}$ \\
\hline EI 37-10 & 485.67 & 500.67 & 533.67 & 541.33 & $515.33 a$ & 215.33 & 235.00 & 250.67 & 257.67 & $239.67 f$ \\
\hline IK $76-79$ & 403.33 & 499.67 & 533.33 & 541.33 & $477.67 \mathrm{c}$ & 220.67 & 232.67 & 250.33 & 257.67 & $240.33 f$ \\
\hline N 11 & 490.67 & 502.33 & 542.33 & 548.33 & $520.92 \mathrm{a}$ & 215.00 & 236.33 & 250.33 & 257.67 & $239.83 \mathrm{f}$ \\
\hline $82 / 4-21$ & 390.67 & 399.67 & 434.33 & 450.33 & $418.75 \mathrm{c}$ & 0.00 & 0.00 & 0.00 & 0.00 & 0.00 \\
\hline $85 / 3-35$ & 0.00 & 0.00 & 0.00 & 0.00 & 0.00 & 0.00 & 0.00 & 0.00 & 0.00 & 0.00 \\
\hline Mean & $445.21 \mathrm{~d}$ & $457.80 \mathrm{c}$ & $472.12 b$ & $481.79 \mathrm{a}$ & 455.64 & $258.87 \mathrm{~d}$ & $268.76 \mathrm{c}$ & $286.85 \mathrm{~b}$ & $296.36 \mathrm{a}$ & 199.55 \\
\hline $\begin{array}{l}\text { LSD } 0.05 \\
\text { S/G }\end{array}$ & \multicolumn{4}{|c|}{5.139} & 8.328 & \multicolumn{4}{|c|}{2.640} & 2.749 \\
\hline $\begin{array}{l}\text { LSD } 0.05 \\
\text { SxG }\end{array}$ & \multicolumn{4}{|c|}{17.076} & & \multicolumn{5}{|c|}{8.772} \\
\hline
\end{tabular}

Whereas: $(0)=$ genotypes were not flowering from beginning

$(-)$ genotypes did not continue flowering

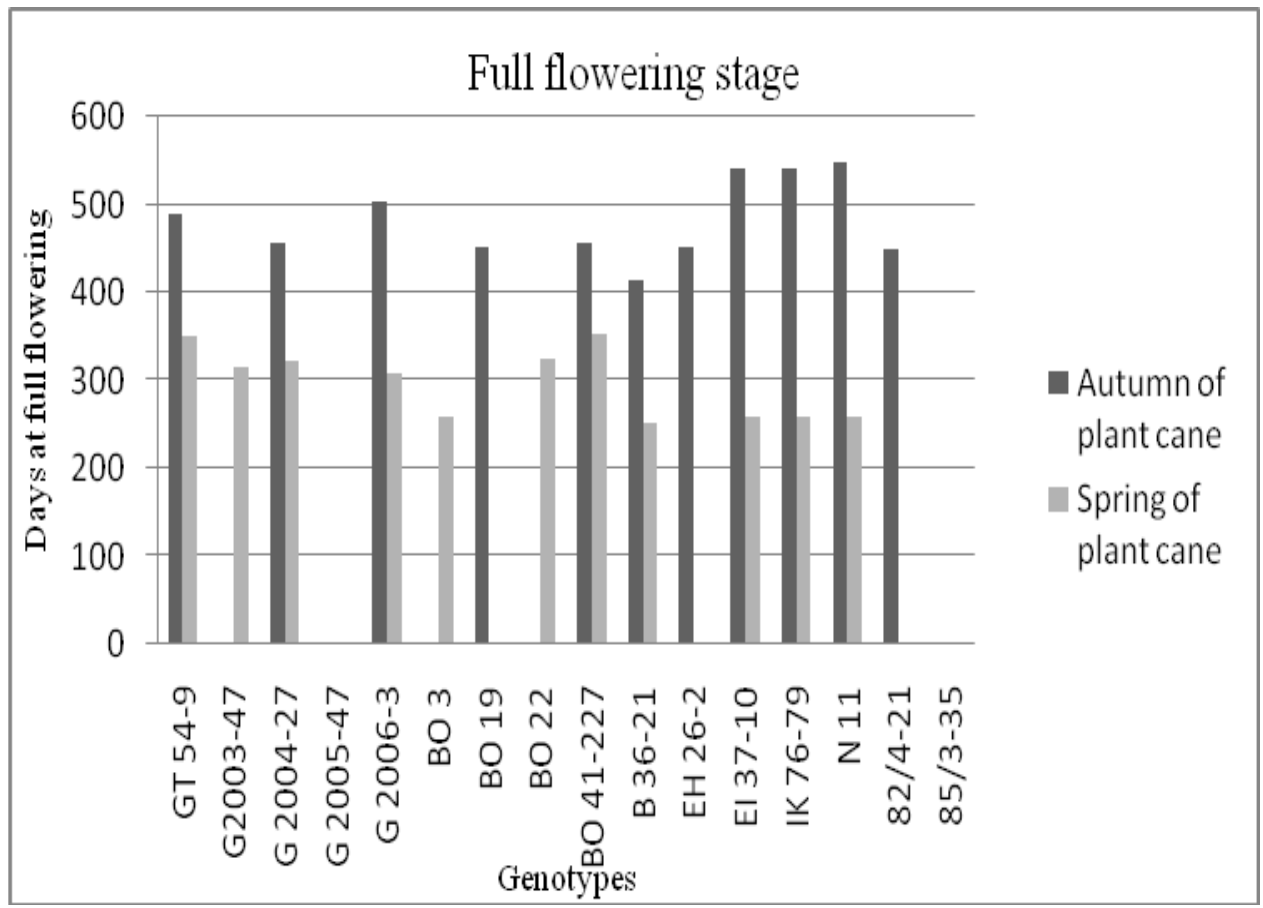

Figure 1. Comparisons between sixteen studied genotypes at full flowering stage of two autumn and spring planting dates of plant cane

* All flowering stages begin from planting date of each season. 
The "ripe to flower" condition occurred with cane of 2-24 months age at induction, with some differences between varieties. There was a slight increase in flowering with cane of increasing age from 3-8 months at induction.

Data in Table (2) revealed that there were also some genotypes that have the same flowering date for full flowering such as BO 19, EH 26-2, 82/4-21 and G 2004-27 which flowered after 450.33 to 455.67 days, also EI 37-10 and IK 76-79 which flowered after 541.33 days in autumn plant cane. The same trend was observed in other planting season. In the spring plant cane, similar flowering dates were found in some genotypes such as BO 3, EI 37-10, IK 76-79 and N 11 which flowered after 257.67 days, as well as BO41-227 and the commercial variety GT54-9 which flowered after 351.67 days, also G 2004-27 and G 2006-3 genotypes which flowered after 322.67 and 308.67 days, respectively, and were closer with flowering date of commercial variety G2003-47 which flowered after 316.33 days (Figure 1). Those genotypes which synchronized with each other can be easily crossed. Moreover, data in Table (3) revealed that, in first ratoon of autumn season, some genotypes gave the same time of flowering like $\mathrm{BO} 3$ and
BO19 which flowered after 275.33 days, also BO41-227 (335.67 days) and EH26-2 genotypes reached full flowered stage after 336.33 days, genotype B36-21 and 82/4-21flowered after 282.33 days. Similarity, first ratoon genotypes in spring season can be easily crossed between them such as BO22 (287.67 days), BO41-227 (287 days) and B 36-21 which reached full stage after 288.33 days (Figure 2).

The obtained findings are in harmony with Berding and Humey (2005) who found that sugarcane varieties behave differently in relation to the number of days required within the inductive period for floral stimulation. Junejo et al. (2012) reported that in all sugarcane experiments, varieties/genotypes were planted during October but flowering in the same varieties/genotypes was exhibited when they attained age of about thirteen to fifteen months. Early and late flowering in different varieties might be due to the difference in maturity period of the varieties/genotypes. On the other hand Melloni et al. (2015) illustrated that one of the difficulties found in their work was the balance between induction and flowering of the genotypes within and among the treatments.

Table 3. Days to flowering stages in some sugarcane genotypes (first ratoon) in different planting seasons

\begin{tabular}{|c|c|c|c|c|c|c|c|c|c|c|}
\hline \multirow{3}{*}{ Genotype } & \multicolumn{4}{|c|}{ Autumn first ratoon } & \multirow{3}{*}{$\begin{array}{l}\text { Genot. } \\
\text { Mean }\end{array}$} & \multicolumn{4}{|c|}{ Spring first ratoon } & \multirow{3}{*}{$\begin{array}{l}\text { Genot. } \\
\text { Mean }\end{array}$} \\
\hline & \multicolumn{4}{|c|}{$2015 / 16$} & & \multicolumn{4}{|c|}{$2015 / 16$} & \\
\hline & Develop. & Flag & Tip & Full & & Develop. & Flag & Tip & Full & \\
\hline GT 54-9 & 0.00 & 0.00 & 0.00 & 0.00 & 0.00 & 184.67 & 204.67 & 219.67 & 227.67 & $209.17 \mathrm{e}$ \\
\hline G2003-47 & 0.00 & 0.00 & 0.00 & 0.00 & 0.00 & 207.67 & 228.33 & - & - & - \\
\hline G 2004-27 & 329.33 & 341.67 & 355.00 & 364.67 & $347.67 \mathrm{~b}$ & 207.00 & 222.00 & - & - & - \\
\hline G 2005-47 & 0.00 & 0.00 & 0.00 & 0.00 & 0.00 & 207.33 & 228.00 & - & - & - \\
\hline G 2006-3 & 0.00 & 0.00 & 0.00 & 0.00 & 0.00 & 213.67 & 237.67 & 256.67 & 270.00 & $244.50 \mathrm{~b}$ \\
\hline BO 3 & 246.67 & 254.67 & 262.33 & 275.33 & $259.75 \mathrm{~g}$ & 206.67 & 218.67 & 247.33 & 257.67 & $232.58 \mathrm{c}$ \\
\hline BO 19 & 250.33 & 261.67 & 268.67 & 275.33 & $264.00 \mathrm{f}$ & 228.00 & - & - & - & - \\
\hline BO 22 & 378.00 & 385.00 & - & - & - & 206.67 & 244.67 & 273.00 & 287.67 & $253.00 \mathrm{a}$ \\
\hline BO 41-227 & 308.67 & 321.67 & 329.67 & 335.67 & $323.92 \mathrm{c}$ & 207.00 & 244.67 & 274.67 & 287.00 & $253.33 a$ \\
\hline B 36-21 & 235.33 & 252.33 & 272.00 & 282.33 & $260.50 \mathrm{~g}$ & 205.67 & 226.67 & 278.33 & 288.33 & $249.75 a$ \\
\hline EH 26-2 & 295.33 & 304.67 & 322.33 & 336.33 & $314.67 d$ & 0.00 & 0.00 & 0.00 & 0.00 & 0.00 \\
\hline EI 37-10 & 0.00 & 0.00 & 0.00 & 0.00 & 0.00 & 190.67 & 216.67 & 230.33 & 238.67 & $219.08 d$ \\
\hline IK 76-79 & 0.00 & 0.00 & 0.00 & 0.00 & 0.00 & 210.33 & 239.33 & 260.67 & 265.33 & $243.92 b$ \\
\hline N 11 & 220.33 & 234.67 & 249.67 & 262.33 & $241.75 \mathrm{~h}$ & 0.00 & 0.00 & 0.00 & 0.00 & 0.00 \\
\hline $82 / 4-21$ & 261.67 & 269.67 & 274.67 & 282.33 & $272.08 \mathrm{e}$ & 200.00 & 217.33 & - & - & - \\
\hline $85 / 3-35$ & 416.33 & 423.00 & 430.33 & 440.33 & $427.50 \mathrm{a}$ & 200.00 & 220.00 & - & - & - \\
\hline Mean & $294.20 \mathrm{c}$ & $307.60 \mathrm{~b}$ & $307.18 b$ & $317.18 \mathrm{a}$ & 306.51 & $205.38 d$ & $226.82 c$ & $255.08 b$ & $265.29 a$ & 238.17 \\
\hline $\begin{array}{c}\text { LSD } 0.05 \\
\text { S/G }\end{array}$ & \multicolumn{4}{|c|}{2.588} & 3.087 & \multicolumn{4}{|c|}{1.739} & 3.119 \\
\hline $\begin{array}{c}\text { LSD } 0.05 \\
\text { SxG }\end{array}$ & \multicolumn{4}{|c|}{7.784} & & \multicolumn{4}{|c|}{4.920} & \\
\hline
\end{tabular}

Whereas: $(0)=$ genotypes were not flowering from beginning

$(-)$ genotypes did not continue flowering 


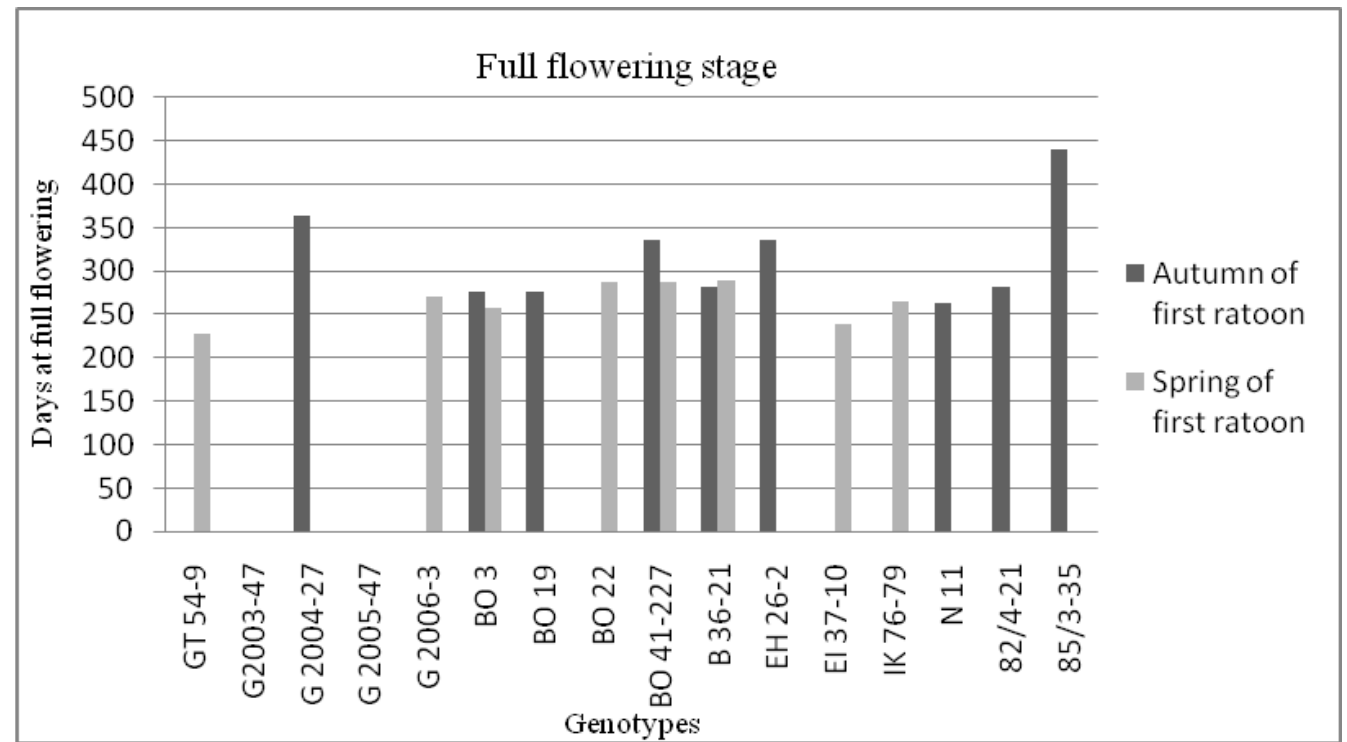

Figure 2. Comparisons between sixteen studied genotypes at full flowering stage of two autumn and spring planting dates of first ratoon

* All flowering stages begin from planting date of each season.

In the present study, some genotypes that did not synchronized with each other at the full flowering stage when planted in the same season, we found them synchronized when they planted in different seasons, such as plant cane in autumn season (Table 2), where the full flowering of genotype G2006-3 was after 502.67 days and genotype BO41-227 was after 455.67 days. It was difficult to make crosses together, but they were easy to cross genotype G2006-3 in autumn planting with genotype BO41-227 in spring planting which reach to full emergence stage together in mid-March, also G 2006-3 in autumn planting can make cross with commercial variety GT 54-9 that planted in spring season, because the flowering date for them very close at mid of March. As well as genotype G2004-27 in autumn planting with genotype G2006-3 in spring planting, that is because the date of their flowering were in last of January to first of February, respectively, regardless the different dates of their planting (Figure 3). Such results confirm that the induction period for both two planting dates happened at the same time (end of September/2014 to mid of October/2014 in plant cane crop). Allam et al. (1978) reported that the time of full emergence, studies on this aspect carried by dissection of the shoot apex have shown that, under Sabahia conditions, the time of initiation is, more or less the same of all categories of varieties, i.e. early-mid and late-season flowering regardless of the tasseling time. The time of flower initiation extends over a period of about one month. Thus initiation which is during the first fortnight of October is over by mid-November for early flowers like NCo310 is full bloom in December, and for late bloomers like Co281, Co290 and POJ213 in

June. Junejo et al. (2012) suggested that the identification of different sugarcane varieties/genotypes with synchronized flowering dates can provide ease to the sugarcane breeders for planting of crossing blocks under natural conditions in the field and controlled conditions in the glass house for quality fuzz production which helps in new sugarcane variety development in the country.

Results in the present study, the behavior of some genotypes to reach the full stage changed by different plantings was also observed. The commercial variety (GT54-9) was flowered in all seasons except autumn of first ratoon, while the commercial variety (G2003-47) was not flowered in all seasons, except spring of plant cane. Genotypes EI 37-10 and IK 76-79 reached to full flowering in all planting, except first ratoon at autumn season (Table 2 and 3). This shows how the different planting dates can affect the flowering dates and behavior of genotypes. As well some genotypes that started flowering and stopped before they reach to full stages. Genotype G2005-47 reached to development stage then it stopped at both autumn and spring planting dates of plant cane crop (Table 2), while flowering of genotypes G2003-47, G2004-27, G 2005-47, 82/4-21 and 85/3-35 stopped at flag stage in spring date of first ratoon crop (Table 3). On the other hand, data in Table (2) revealed that the commercial variety (G2003-47) and genotype 85/3-35 were not flowered from the beginning in autumn planting season of plant cane, as well as genotypes EH 26-2, 82/4-21 and 85/3-35 in spring planting of plant cane. The same trend was observed on planting seasons at first ratoon (Table 3). Colvill and Marshall (1984) reported the age of sugarcane may 
promote or inhibit floral initiation. The obtained results are in accordance with Shanmugavadivu and Gururaja Rao (2009) who suggested that the influence of climate conditions on flowering and the intensity of this process will be also controlled by the genotype, since for the same climate conditions some genotypes present flowers whereas others not. Donna Glassop et al. (2014) suggested that without a "persistent pressure" during the floral development process, sugarcane will revert back to vegetative growth. The reasons behind lack of floral induction are unknown and there is an essential importance to research if floral induction on demand is to be successful.

Table (2) showed planting dates caused difference in mean values of flowering stages. This difference ranged from 258.87 - 445.21, 268.76 - 457.80, 286.85 - 472.12 and 296.36 - 481.79 days for development, flag, tip, and full stages of flowering in spring and autumn plant cane respectively. Also, different range of flowering stages mean values were observed between spring and autumn planting seasons of first ratoon (Table 3). The data showed that some varieties reach to development stage later than other but flowered earlier or in the same time such as EI 37-10 genotype which reached to development stage after 485.67 days later than IK 76-79 genotype which reached earlier to the same stage after 403.33 days from planting, although the two genotypes reached to full flowering stage in the same time after 541.33 days in autumn season of plant cane (Table 2). The Indian researchers found that the time of initiation among clones to be essentially the same regardless of time of flower emergence. On the other hand, Vijayasaradhy and Narasimhan, 1954 found relation between time of flowering and rate of development of inflorescences. For the same genotype, the different flowering stages may occur due to the environmental conditions which change from season to season. Allam et al. (1978) reported that differences in the time of flower emergence in some cases (lasting six months) may be attributed to the slow growth of the inflorescence primordium partially due to low temperatures. When the temperatures become favorable in May, normal growth takes place and the arrows are pushed out.

Table (4) shows the difference in temperature, humidity and length of day in seasons (2013/14/15) and $(2015 / 16)$ on monthly mean, and this is in turn affect the flowering initiation in different stages at different seasons. This may explain why flowering initiation changed from season to another. It also proved that these environmental factors have a significant role in the flowering of sugar cane.

According to Rao et al. (1973) Alexandria, Egypt, typifies the conditions of temperature and humidity ideal for floral induction. The optimum nycte period of 11:30 to 12:00 hours occurs from the last week of September to mid-October. El-Sabahia cane flowering site is coastal area situated at Alexandria ( $31^{\circ} 12 \mathrm{~N}$ latitude) where almost 18 photo inductive days are available for exposure of cane varieties to required photoperiod (11.30-12.00 hrs) from 26 September to 13 October (Table 5 and Figure 4\&5). In the northern hemisphere, flower emergence begins near the equator before or during the autumn equinox (about September 22) and gradually progresses northward to reach $10^{\circ} \mathrm{N}$ by October, $20^{\circ} \mathrm{N}$ during November, and $30^{\circ} \mathrm{N}$ in December (Brett 1951 and Mangelsdorf 1956). Clements and Awada (1964) stated that optimum flowering hours is 11.30 hours and flowering is more profuse near to equator that away from it.

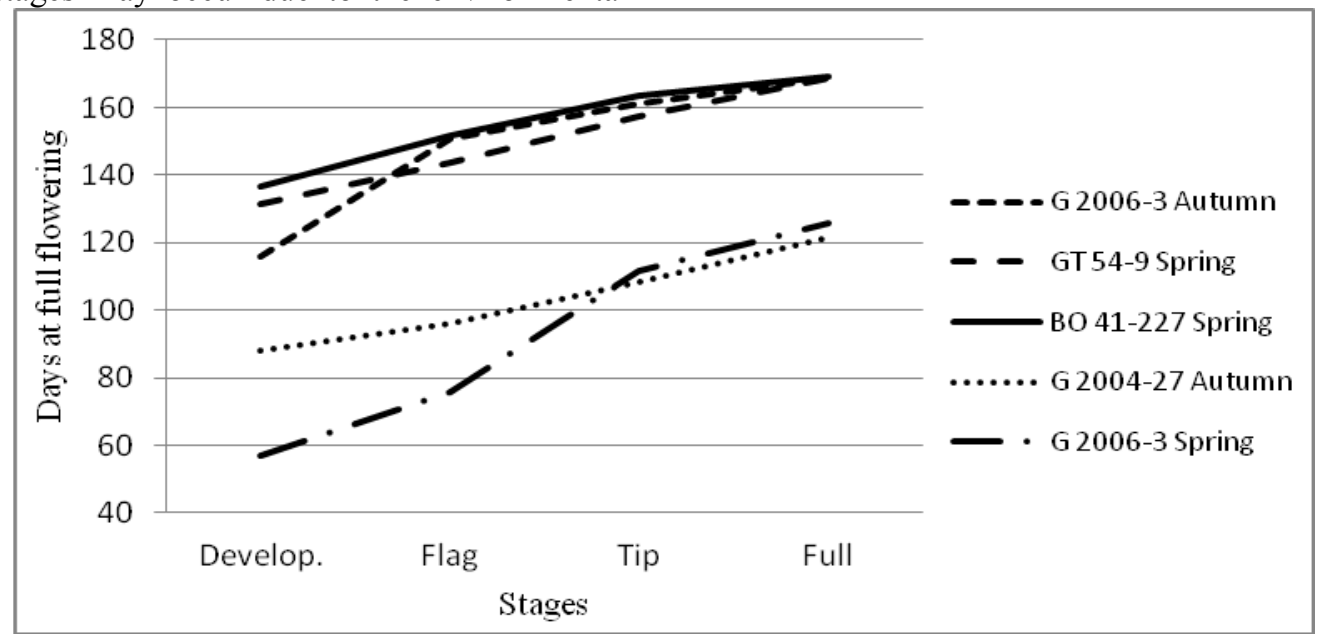

Figure 3. Genotypes at different planting seasons but synchronized at full emergence stage

* All flowering stages begin from first of October 
Table 4. Temperature, humidity and length of day in different seasons 2013/14/15/16

\begin{tabular}{|c|c|c|c|c|c|c|c|c|c|}
\hline \multirow{3}{*}{ Months } & \multicolumn{4}{|c|}{ 2013/14/15 } & \multirow{3}{*}{ Months } & \multicolumn{4}{|c|}{$2015 / 16$} \\
\hline & \multicolumn{2}{|c|}{ Temperature ${ }^{\circ} \mathrm{C}$} & \multirow{2}{*}{$\begin{array}{c}\text { Humidity } \\
\%\end{array}$} & \multirow{2}{*}{$\begin{array}{c}\text { Length of } \\
\text { day }\end{array}$} & & \multicolumn{2}{|c|}{ Temperature ${ }^{\circ} \mathrm{C}$} & \multirow{2}{*}{$\begin{array}{c}\text { Humidity } \\
\% \\
\end{array}$} & \multirow{2}{*}{$\begin{array}{c}\text { Length of } \\
\text { day }\end{array}$} \\
\hline & Max & Min & & & & $\operatorname{Max}$ & Min & & \\
\hline 15/Oct. & 19 & 13 & 66.1 & $11 \mathrm{~h} 25 \mathrm{~m}$ & 15/Apr. & 24 & 13 & 66 & $12 \mathrm{~h} 55 \mathrm{~m}$ \\
\hline 15/Nov. & 24 & 16 & 72.9 & $10 \mathrm{~h} 34 \mathrm{~m}$ & 15/May & 31 & 19 & 64 & $13 \mathrm{~h} 43 \mathrm{~m}$ \\
\hline 15/Dec. & 23 & 8 & 72.5 & $10 \mathrm{~h} 08 \mathrm{~m}$ & 15/Jun. & 30 & 22 & 65 & $14 \mathrm{~h} 09 \mathrm{~m}$ \\
\hline 15/Jan. & 17 & 12 & 83 & $10 \mathrm{~h} 20 \mathrm{~m}$ & 15/Jul. & 31 & 24 & 66 & $13 \mathrm{~h} 59 \mathrm{~m}$ \\
\hline 15/Feb. & 19 & 12 & 85 & $11 \mathrm{~h} 05 \mathrm{~m}$ & 15/Aug. & 31 & 27 & 53 & $13 \mathrm{~h} 17 \mathrm{~m}$ \\
\hline 15/Mar. & 21 & 14 & 66 & $11 \mathrm{~h} 57 \mathrm{~m}$ & 15/Sep. & 30 & 26 & 61 & $12 \mathrm{~h} 22 \mathrm{~m}$ \\
\hline 15/Apr. & 26 & 17 & 69 & $12 \mathrm{~h} 55 \mathrm{~m}$ & 15/Oct. & 28 & 19 & 60 & $11 \mathrm{~h} 26 \mathrm{~m}$ \\
\hline 15/May & 31 & 18 & 65 & $13 \mathrm{~h} 44 \mathrm{~m}$ & 15/Nov. & 24 & 18 & 71 & $10 \mathrm{~h} 35 \mathrm{~m}$ \\
\hline 15/Jun. & 31 & 22 & 71 & $14 \mathrm{~h} 09 \mathrm{~m}$ & 15/Dec. & 19 & 13 & 71 & $10 \mathrm{~h} 08 \mathrm{~m}$ \\
\hline 15/Jul. & 29 & 26 & 71 & $13 \mathrm{~h} 59 \mathrm{~m}$ & 15/Jan. & 18 & 10 & 58 & $10 \mathrm{~h} 20 \mathrm{~m}$ \\
\hline 15/Aug. & 30 & 26 & 68 & $13 \mathrm{~h} 17 \mathrm{~m}$ & 15/Feb. & 21 & 9 & 60 & $11 \mathrm{~h} 04 \mathrm{~m}$ \\
\hline 15/Sep. & 29 & 23 & 66 & $12 \mathrm{~h} 22 \mathrm{~m}$ & 15/Mar. & 22 & 14 & 64 & $11 \mathrm{~h} 58 \mathrm{~m}$ \\
\hline 15/Oct. & 27 & 21 & 72 & $11 \mathrm{~h} 25 \mathrm{~m}$ & 15/Apr. & 28 & 18 & 55 & $12 \mathrm{~h} 56 \mathrm{~m}$ \\
\hline 15/Nov. & 22 & 17 & 66 & $10 \mathrm{~h} 34 \mathrm{~m}$ & 15/May & 33 & 19 & 31 & $13 \mathrm{~h} 44 \mathrm{~m}$ \\
\hline 15/Dec. & 19 & 13 & 72 & $10 \mathrm{~h} 08 \mathrm{~m}$ & 15/Jun. & 32 & 23 & 61 & $14 \mathrm{~h} 10 \mathrm{~m}$ \\
\hline 15/Jan. & 19 & 9 & 73 & $10 \mathrm{~h} 20 \mathrm{~m}$ & 15/Jul. & 28 & 26 & 60 & $13 \mathrm{~h} 58 \mathrm{~m}$ \\
\hline 15/Feb. & 20 & 10 & 75 & $11 \mathrm{~h} 05 \mathrm{~m}$ & 15/Aug. & 29 & 26 & 54 & $13 \mathrm{~h} 16 \mathrm{~m}$ \\
\hline 15/Mar. & 20 & 13 & 53 & $11 \mathrm{~h} 57 \mathrm{~m}$ & 15/Sep. & 30 & 23 & 54 & $12 \mathrm{~h} 21 \mathrm{~m}$ \\
\hline
\end{tabular}

* Source: Whether underground site.

Table 5. Temperature, humidity and length of day in September and October 2014/15 seasons

\begin{tabular}{|c|c|c|c|c|c|c|c|c|c|}
\hline \multirow{3}{*}{ Days } & \multicolumn{4}{|c|}{ September and October/2014 } & \multirow{3}{*}{ Days } & \multicolumn{4}{|c|}{ September and October/2015 } \\
\hline & \multicolumn{2}{|c|}{ Temperature $^{\circ} \mathrm{C}$} & \multirow{2}{*}{$\begin{array}{c}\text { Humidity } \\
\%\end{array}$} & \multirow{2}{*}{$\begin{array}{l}\text { Length of } \\
\text { day }\end{array}$} & & \multicolumn{2}{|c|}{ Temperature ${ }^{\circ} \mathrm{C}$} & \multirow{2}{*}{$\begin{array}{c}\text { Humidity } \\
\%\end{array}$} & \multirow{2}{*}{$\begin{array}{c}\text { Length of } \\
\text { day }\end{array}$} \\
\hline & Max & Min & & & & Max & Min & & \\
\hline 26/Sep. & 30 & 25 & 69 & $12 \mathrm{~h} 01 \mathrm{~m}$ & 26/Sep. & 33 & 25 & 62 & $12 \mathrm{~h} 01 \mathrm{~m}$ \\
\hline 27/Sep. & 33 & 23 & 69 & $11 \mathrm{~h} 59 \mathrm{~m}$ & 27/Sep. & 31 & 21 & 62 & $11 \mathrm{~h} 59 \mathrm{~m}$ \\
\hline 28/Sep. & 28 & 24 & 56 & $11 \mathrm{~h} 57 \mathrm{~m}$ & 28/Sep. & 32 & 22 & 61 & $11 \mathrm{~h} 58 \mathrm{~m}$ \\
\hline 29/Sep. & 28 & 22 & 58 & $11 \mathrm{~h} 55 \mathrm{~m}$ & 29/Sep. & 32 & 22 & 63 & $11 \mathrm{~h} 56 \mathrm{~m}$ \\
\hline 30/Sep. & 28 & 18 & 65 & $11 \mathrm{~h} 53 \mathrm{~m}$ & 30/Sep. & 28 & 22 & 67 & $11 \mathrm{~h} 54 \mathrm{~m}$ \\
\hline 1/Oct. & 28 & 18 & 61 & $11 \mathrm{~h} 51 \mathrm{~m}$ & 1/Oct. & 28 & 22 & 59 & $11 \mathrm{~h} 52 \mathrm{~m}$ \\
\hline 2/Oct. & 28 & 18 & 57 & $11 \mathrm{~h} 50 \mathrm{~m}$ & 2/Oct. & 29 & 21 & 65 & $11 \mathrm{~h} 50 \mathrm{~m}$ \\
\hline 3/Oct. & 28 & 22 & 57 & $11 \mathrm{~h} 48 \mathrm{~m}$ & 3/Oct. & 29 & 25 & 60 & $11 \mathrm{~h} 48 \mathrm{~m}$ \\
\hline 4/Oct. & 27 & 22 & 52 & $11 \mathrm{~h} 46 \mathrm{~m}$ & 4/Oct. & 28 & 23 & 54 & $11 \mathrm{~h} 46 \mathrm{~m}$ \\
\hline 5/Oct. & 27 & 20 & 64 & $11 \mathrm{~h} 44 \mathrm{~m}$ & 5/Oct. & 28 & 23 & 51 & $11 \mathrm{~h} 44 \mathrm{~m}$ \\
\hline 6/Oct. & 28 & 19 & 65 & $11 \mathrm{~h} 42 \mathrm{~m}$ & 6/Oct. & 28 & 23 & 58 & $11 \mathrm{~h} 43 \mathrm{~m}$ \\
\hline 7/Oct. & 29 & 21 & 70 & $11 \mathrm{~h} \mathrm{40m}$ & 7/Oct. & 29 & 22 & 60 & $11 \mathrm{~h} 41 \mathrm{~m}$ \\
\hline 8/Oct. & 29 & 22 & 70 & $11 \mathrm{~h} 38 \mathrm{~m}$ & 8/Oct. & 30 & 21 & 61 & $11 \mathrm{~h} 39 \mathrm{~m}$ \\
\hline 9/Oct. & 29 & 19 & 71 & $11 \mathrm{~h} 37 \mathrm{~m}$ & 9/Oct. & 29 & 24 & 56 & $11 \mathrm{~h} 37 \mathrm{~m}$ \\
\hline 10/Oct. & 28 & 21 & 65 & $11 \mathrm{~h} \mathrm{35m}$ & 10/Oct. & 29 & 24 & 55 & $11 \mathrm{~h} 35 \mathrm{~m}$ \\
\hline 11/Oct. & 28 & 19 & 65 & $11 \mathrm{~h} 33 \mathrm{~m}$ & 11/Oct. & 29 & 20 & 61 & $11 \mathrm{~h} 33 \mathrm{~m}$ \\
\hline 12/Oct. & 28 & 18 & 66 & $11 \mathrm{~h} 31 \mathrm{~m}$ & 12/Oct. & 32 & 19 & 69 & $11 \mathrm{~h} 31 \mathrm{~m}$ \\
\hline 13/Oct. & 29 & 18 & 68 & $11 \mathrm{~h} 29 \mathrm{~m}$ & 13/Oct. & 29 & 20 & 75 & $11 \mathrm{~h} 30 \mathrm{~m}$ \\
\hline
\end{tabular}

* Source: Whether underground site. 


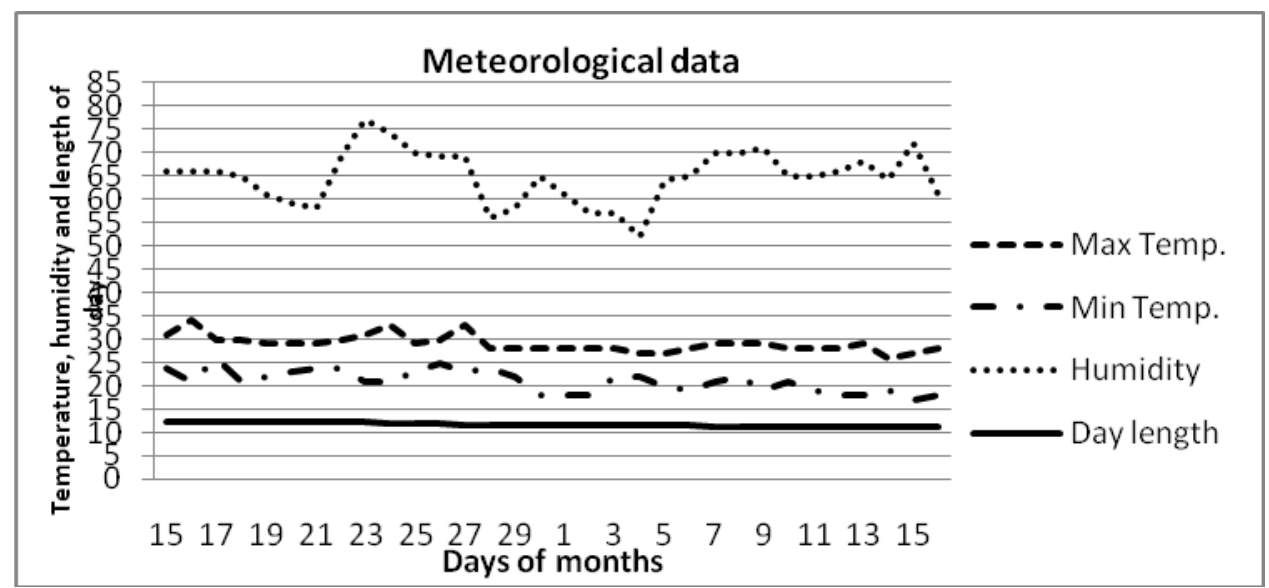

Figure 4. Summary of meteorological data during last half of September to mid-October 2014 season * Source: Whether underground site

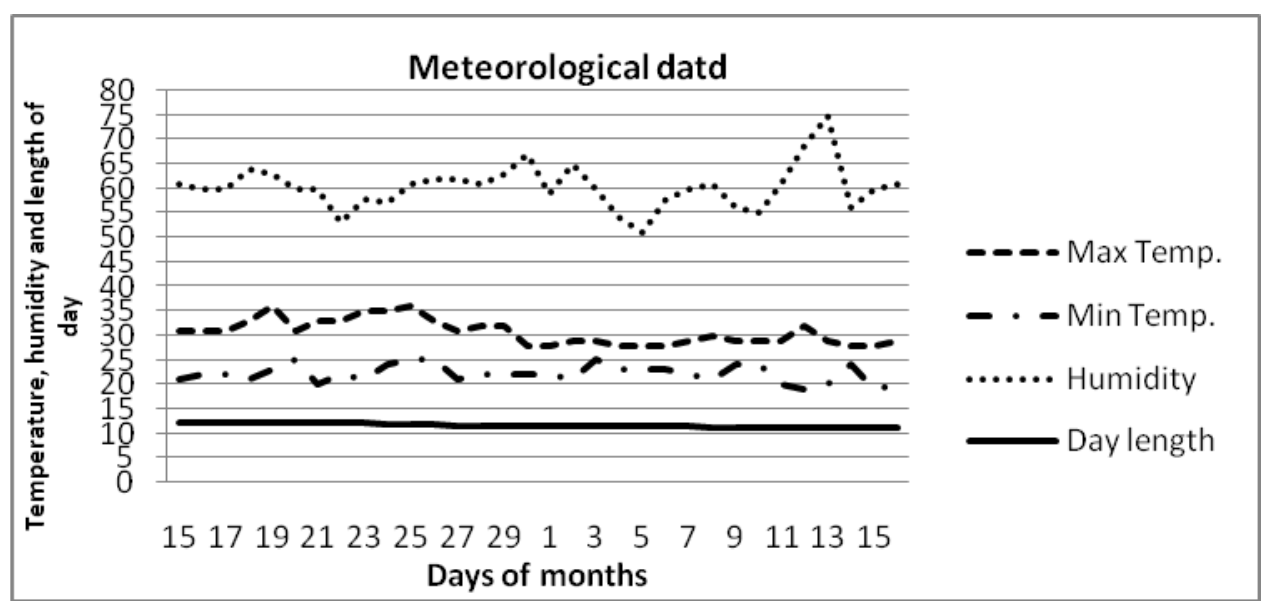

Figure 5. Summary of meteorological data during last half of September to mid-October 2015 season

* Source: Whether underground site.

From (Table 5 and Figures 4\&5) daily mean of photoperiod and temperature are not far beyond the required range for most of the cane genotypes during flowering inductive phase (September and October). The meteorological data in Sabahia research station, Alexandria, Egypt from last week of September to mid of October in two successive seasons 2014 and 2015 illustrated that the average of maximum and minimum temperature of inductive phase in 2014 and 2015 seasons were $(28.5 \quad \& \quad 20.5)$ and $(29.6 \quad \& \quad 22.2)$ respectively. Also, the photoperiod ranged from 12 to 11.30 hours from last week of September to mid of October respectively. As well as the average of humidity percentage of inductive phase in two seasons 2014 and 2015 were $63.8 \%$ and $61.1 \%$, respectively. It could be discussed why most of the cane genotypes could show flowering under natural conditions of Sabahia. Sugarcane flowering is a complex physiological process consisting of multiple stages of development, each stage having specific environmental and physiological requirements (Julien, 1970).

Early workers repeatedly referred to a few classical studies which elegantly demonstrated that sugarcane was an intermediate day length plant (IDP) flowering under day lengths of 12.5 to 11.5 hours (Allard 1938 and Sartoris 1939). Recent recognition of flowering stages having different photoperiod requirements (Julien, 1972 and Midmore, 1980) may reconcile the two classifications of (intermediate Day length plant, IDP) and (short day plants, SDP). Apparently, the photoperiod requirements of the various floral stages are best met by intermediate day lengths followed by gradually shorter days. We classify sugarcane on the basis of initial induction as an IDP while recognizing the development of the panicle and flowers as a quantitative short day response. Extensive research also categorized sugarcane as a quantitative intermediate day plant, with later developmental stages requiring shorter day length (Berding and Moore 2001 and Berding et al., 2007, 
2010). Miah and Paul (2008) illustrated that photoperiod is the principal desirable factor for controlling the flowering in sugarcane. In this crop, flowering shows a range of variation among the varieties. Melloni et al. (2015) reported that flowering is essential to any breeding programme to promote crosses. Floral induction is usually observed prior to panicle emergence through stalk elongation, lateral sprouting and flag leaf emission. The stalk size increases when the day length ranged between 12 hour 55 minute to 11 hour 30 minute which occurs during the inductive photoperiod.

The daytime optimum temperature is around $28^{\circ} \mathrm{C}$ (Clements and Awada, 1967) and the nighttime optimum is about $23^{\circ} \mathrm{C}$ (Nuss, 1980). This narrow range of temperature optimal led Clements and Awada (1967) to propose that the small $\left(5^{\circ} \mathrm{C}\right)$ temperature difference between day and night was more important for flowering than were the actual temperature extremes. Intermittent occurrences of night temperatures below $18^{\circ} \mathrm{C}$ during the period of floral induction have been reported to reduce flowering intensity or delay emergence (Coleman, 1963 and Gosnell, 1973). Similarly, frequent occurrences of day time temperatures exceeding $31^{\circ} \mathrm{C}$ have been reported to severely reduce flowering intensity or early emergence (Ellis et al., 1967, Nuss and Brett, 1977). Shanmugavadivu and Gururaja Rao (2009) reported that the reduction in flowering ability of clones in the traditional breeding plots could be due to high temperature prevailing prior to and during the floral initiation period and deficient rainfall. Malik (2011) observed that during flower induction period, the mean maximum and minimum temperatures are $33^{\circ} \mathrm{C}$ and 25

${ }^{\circ} \mathrm{C}$ respectively, which are close to inductive ranges and diurnal variation in temperature is not much wide. LaBorde et al. (2014) suggested that the variation in sugarcane tasseling percentages that have been encountered over the years when above average temperatures were experienced. Methods, such as misting systems and fans, for lowering temperatures during these periods should be explored to help breeding programs maximize tasseling.

Adequate moisture is critical not only for induction and development, but for timing emergence and anthesis and regulating seed set. Both flower opening and anthesis are affected by relative humidity, for flower opening and anther extrusion usually occur several hours before sunrise, when the plant is fully hydrated and the relative humidity is high. Anthesis occurs as the relative humidity is dropping near sunrise (Dutt et al.,1939). The pollen shed is rapidly desiccated and has a half-life of only 20 to 30 minutes (Moore, 1976). Low humidities at anthesis lead to poor seed set (Nuss, 1979). Melloni et al. (2014) reported that the environment influence (temperature and humidity) had an important role during the poly cross. Mehareb et al. (2016) suggested that a better understanding of temperature and relative humidity that affects on sugarcane flowering is important to study behavior of genotypes flowering and make synchronization for crossing in future between these genotypes. Also, the extreme coastal climatic conditions of the area near to sea shore might have favored the sugarcane to produce high flowering intensity. Sugarcane flowers naturally under Sabahia conditions, but the number of genotypes flowered varied between different planting dates. Data in Table (6) illustrated the percentage of total flowered plants. There was a significant difference between flowering percentage at different planting dates. The total percentage was ranged from $9.11 \%$ for genotype EI 37 10 to $22.72 \%$ for genotype G $2006-3$ in plant cane of autumn season and ranged from $6.62 \%$ for the commercial variety G2003-47 to $22.52 \%$ for genotype BO 41-227 in plant cane of spring season. On the other hand flowering percentage slightly increased in ratoon can which varied from $11.29 \%$ for genotype G 2004-27 to $26.23 \%$ for genotype BO 19 in autumn of first ratoon while in spring first ratoon varied from $11.01 \%$ for genotype G 2006-3 to $25.74 \%$ for genotype BO 41-227, while number of flowering genotypes in plant cane was higher than first ratoon in two seasons. Both BO41-227 and B36-21 genotypes flowered under both plant cane and first ratoon in autumn and spring seasons. Similar results were reviewed by Brett (1951) who reported that greater intensity of flowering occurred in the second year than in the first year. Similar observations were reported by Junejo et al. (2012) who found that flowering occurred in most of the cane varieties under natural environment but the time, intensity and percentage of flowered varieties differed widely between the years of the same environment. Durai et al. (2014) reported that information on flowering intensity or propensity was useful for the breeders to decide number cross combinations possible using the particular parent. Mohamed et al. (2016) suggested that sugarcane plants were different in flowering behavior from plant cane to first ratoon, but performance of genotypes under first ratoon was more than plant cane.

Finally, it was found that genotypes could be synchronizing in the same season or in the different seasons at the time of full flowering stage. The ideal location for flowering and large amount of germplasm as Sabahia Research Station, Alexandria, Egypt must be put under evaluation on national level for selection of suitable parents that can be synchronized timely for future hybridization and breeding programs. 
Table 6. Percentage of total flowered plants in different planting seasons

\begin{tabular}{|c|c|c|c|c|}
\hline \multirow{3}{*}{ Genotype } & \multicolumn{4}{|c|}{$\%$ of total flowered plants } \\
\hline & \multicolumn{2}{|c|}{$2013 / 14 / 15$} & \multicolumn{2}{|c|}{ 2015/16 } \\
\hline & Aut. P.C. & Spr.P.C. & Aut. F.R. & Spr.F.R. \\
\hline GT 54-9 & 12.66 & 16.24 & - & 21.25 \\
\hline G2003-47 & - & 6.62 & - & - \\
\hline G 2004-27 & 14.76 & 10.47 & 11.29 & - \\
\hline G 2005-47 & - & - & - & - \\
\hline G 2006-3 & 22.72 & 7.37 & - & 11.01 \\
\hline BO 3 & - & 10.80 & 17.37 & 17.49 \\
\hline BO 19 & 20.30 & - & 26.23 & - \\
\hline BO 22 & - & 17.50 & - & 19.17 \\
\hline BO 41-227 & 14.81 & 22.52 & 21.76 & 25.74 \\
\hline В 36-21 & 14.22 & 10.83 & 25.83 & 15.69 \\
\hline EH 26-2 & 10.82 & - & 12.75 & - \\
\hline EI 37-10 & 9.11 & 8.61 & - & 13.26 \\
\hline IK 76-79 & 15.00 & 12.48 & - & 15.14 \\
\hline N 11 & 16.94 & 14.50 & 12.35 & - \\
\hline $82 / 4-21$ & 12.54 & - & 17.27 & - \\
\hline $85 / 3-35$ & - & - & 24.05 & - \\
\hline LSD 0.05 & 2.93 & 1.67 & 1.15 & 1.13 \\
\hline
\end{tabular}

\section{REFERENCES}

Ahmed, M.S. and D.A. Gardezi. 2017. Multivariate analysis in determining morphologically diverse sugarcane genotypes (Saccharum officinarum L.) and their response to flowering at Arja, Azad Kashmir. Sarhad J. Agric, 33(1): 90-102.

Allam. A.I., A.H. Nour and T.A. Fayed 1978. Effect of nitrogen and moisture on sugarcane flowering. Proc. Int. Soc. Sugar Cane Technol., (16): 875-882.

Allard, H.A. 1938. Complete or partial inhibition of flowering in certain plants when days are too short or too long. J. Agric. Res., 57: 775-789.

Araldi, R., F.M.L. Silva, E.O. Ono and J.D. Rodrigues 2010. Floweing in sugarcane. Ciencia Rural, 40:694-702.

Berding, N., and P.H. Moore 2001. Advancing from opportunistic sexual recombination in sugarcane: Lessons from tropical photoperiodic research. Proc. Int. Soc. Sugar Cane Technol., 24: 482-487.

Berding, N. and A.P. Humey 2005. Flowering and lodging, physiological-based traits affecting cane and sugar yield, What do we know of their control mechanisms and how do we manage them? Field Crops Res., 92:261-275.

Berding, N., R.S. Pendrigh, and V. Dunne 2007. Can flowering in sugarcane behavior by use of differential declinations for the initiation and development phases? Proc. Int. Soc. Sugar Cane Technol., 26:699-711.

Berding, N., R.S. Pendrigh, and V. Dunne 2010. Pursuing higher efficacy for managed photoperiodic initiation of sugarcane flowering in the tropics. Sugarcane Int., 32(5):234-250.
Brett, P.G.C. 1951. Flowering and pollen fertility in relation to sugar-cane breeding in Natal. Proc. Int. Soc. Sugar Cane Technol., 7: 43-56.

Clements, H.F. and M. Awada 1967. Experiments on the artificial induction of flowering in sugarcane. Proc. Int. Soc. Sugar Cane Technol., 12: 795-812.

Clements, R.E. and M. Awada 1964. Factors affecting the flowering of sugarcane. Indian J. Sugarcane Res. and Develop., 8:140-159.

Coleman, R.E. 1959. Factors involved in the flowering of sugarcane. Proc. 10 Congress Int. Soc. Sugar Cane Technol., Hawaii., 10: 805-813.

Coleman, R.E. 1963. Effect of temperature on flowering of sugarcane. Int. Sugar J., 65: 351-354.

Coleman, R.E. 1968. Physiology of flowering in sugarcane. Proc. Int. Soc. Sugarcane Technol., $13^{\text {th }}$ Congress, Taiwan. Pp. 1968-1969.

Colvill, K. E. and C. Marshall 1984. Tiller dynamics and assimilate partitioning in Lolium perenne with particular reference to flowering. Ann. Appl. Biol., 104:543-557.

Daniels, J. 1962. Experimental control of flowering in (Saccharurn spontaneurn L). Proc. ISSCT, 11 : 527-533.

Donna Glassop, Annel. Rae. Graham and D. Bonnett 2014. Sugarcane flowering genes and pathways in relation to vegetative regression. SugarTech., 16(3) 235-240.

Durai A. A., P. Govindaraj and A. S. Pazhany 2014. Flowering behaviour of sugarcane genotypes from different agro climatic zones of india. Sugar Tech., 16(2):157-163.

Dutt, N.L., M.K. Krishnaswami and K.S.S. Rao 1939. On certain floral characters in sugarcane-1. Proc. Int. Soc. Sugar Cane Technol., 6: 154-170. 
Ellis T.O., J.F. Van Breemen and G. Arceneaux 1967. Flowering of sugarcane in relation to maximum temperature during the induction period. Pro. Int. Soc Sugar Cane Technol., 12: 790-794.

George, E.F., and J.A. Lalauette 1962. Photoperiodic experiments in the sugarcane variety Cp. 36-13. Proc. ISSCT, 11: 516-527.

Gosnell JM 1973. Some factors affecting flowering in sugarcane. Proc South Afr. Sugar Cane Technol. Assoc., 47: 144-147.

James, N.I. 1972. Delayed flowering of Saccharurn spontaneum L. and related hybrids. Crop ISSCT, 12:425427.

Julien, M.H.R. 1970. Investigations on the physiology of flowering. Mauritius Sugar Ind. Res. Rept. pp. 36-39.

Julien, M.H.R. I972. The photoperiodic control of flowering in Saccharum. Proc. Int. Soc. Sugar Cane Technol., 14: 323-333.

Junejo, R.N. Panhwar, B.R. Kazi, A.A. Junjo, U.A. Talpur, G.M. Kaloi and M. Zubair 2012. Study of sugarcane germplasm varieties for flowering abiliaty under agroclimatic conditions of thatta. J. Animal and plant Sci., 22(3):688-694.

LaBorde C., C. Kimbeng, K. Gravois and K. Bischoff 2014. Temperature effects on sugarcane tassel production under artificial photoperiod regimes. J. American Soc. Sugar Cane Technol., 34: 33-43.

Malik, K. B. 2011. Cane and sugar production. Published by Punjab Agric. Res. Board. Technol. for the prosperity of agric. stakeholders. Pp. 52.

Mangelsdorf, A.J. 1956. Sugar cane breeding: In retrospect and in prospect. Proc. Int. Soc. Sugar Cane Technol., 9: 560-575.

McIntyre, C.L and P.A. Jackson 2001. Low level of selfing found in a sample of crosses in Australian sugarcane breeding programs. Euphytica., 117: 245-249.

Mehareb E.M., E.S.R. Salem and M.A. Ghonema 2016. Effects of environmental factors on sugarcane flowering under natural conditions in Egypt. Egypt. J. Plant Breed, 20(6): $1093-1105$.

Melloni, M.L.G., M.N.G. Melloni., M.S. Scarpari., J.C. Garcia., M.G.A. Landell. and L.R. Pinto 2015. Flowering of sugarcane genotypes under different artificial photoperiod conditions. American J. Plant Sci. 6:456-463.

Melloni M.L.G., M.S. Scarpari, L.R. Pinto, D. Perecin, M.A. Xavier and M.G.A.Landell 2014. Selfing rate estimation in sugarcane under unfavorable natural conditions of crossing by using microsatellite markers. Genet. Mol. Res., 13 (1): 2278-2289.

Miah, M. A. and N. K. Paul 2008. Effect of photo periodic treatments on tasseling in sugarcane. Pakistan Sugar J., 23(03):12-17.

Midmore, D.J. 1980. Effects of photoperiod on flowering and fertility of sugarcane (Saccharum spp.). Field Crops Res., 3: $65-81$

Mohamed, B. D., E. A. Mahmoud, H. H. El-Hennawi and E. M. Mehareb 2016. Sugarcane flowering in relation to nitrogen fertilization and ratoon. Direct Res. J. Agric. Food Sci., Vol. 4(7): 155-160.

Moore, P.H. 1976. Studies on sugarcane pollen. II. Pollen storage. Phyton, 34:71-80.

Moore, P. H. and K. J. Nuss 1987. Flowering and flower synchronization. In: Sugarcane Improvement Through Breeding by Heinz D.J. ed. Elsevier, Amsterdam, New York, Tokyo, pp. 273-311.

Nuss, K.J. 1979. Factors influencing the numbers of seedlings obtained from sugarcane crosses. Proc. South Afr. Sugar Technol., 53: 167-169.

Nuss, K.J. 1980. Effects of photoperiod and temperature on initiation and development of flowers in sugarcane. Proc. Int. Soc. Sugar Cane Technol., 17:486-493.

Nuss K.J. and P.G.C. Brett 1977. Artificial induction of flowering in a sugarcane breeding programme. Proc. South. Afr. Genet. Soc., 6: 54-64.

Rao, J.T., A.H. Nour and M.A. El-Manhaly 1973. Flowering of sugarcane in Egypt. Int. Sugar J., 75: 241 -244.

Sartoris, G.B. 1939. The behavior of sugarcane in relation to length of day. Proc. Int. Soc.Sugar Cane Technol., 6: 796801.

Shanmugavadivu, R., and P. Gururaja Rao 2009. A comparison of flowering behavior of sugarcane clones in two different locations. Sugarcane Technol., 11 (4): 401404.

Vijayasaradhy, M. and R. Narasimhan 1954. Control of flowering in sugar cane. Proc. ISSCT., 8: 371-401. 


\section{الملخص العربي}

تزامن التزهير في بعض التزاكيب الور اثية من قصب السكر وذلك في مواسم زراعة مختلفة تحت الظروف الطبيعية

محمد عبد المنعم غنيمه

ـاخل نفس الميعاد الواحد، فلوحظ ان نسب التز هير لمعظــــ التز اكيب الوراثية في الخلفة الاولي اعلي منها في القـصب

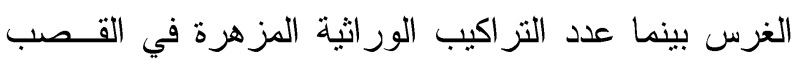

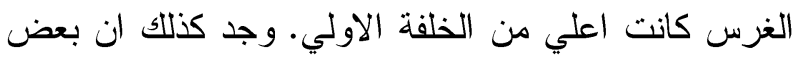

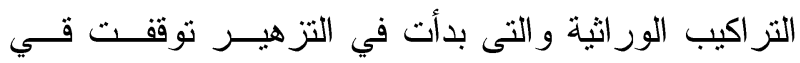

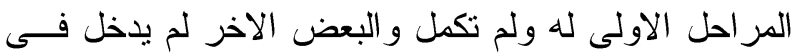
عملية التزهير من الاصل وذلك في جميع مواعيد الزر اعة

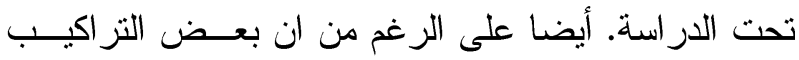

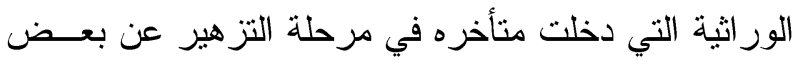

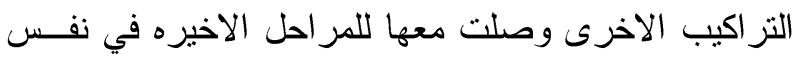
التوقيت. وبصفة عامة وجد ان المر احل المبكره للتزهير في الاصول الوراثية من قصب السكر تحت الدراسة بدأت في شهر نوفمبر بينما الوصول لمرحلة التزهير الكامل وظهور

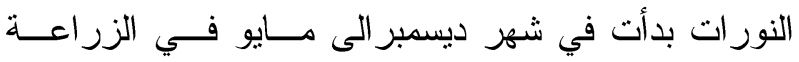
الخريفي للقصب الغرس وفي الزر اعة الربيعى بدأت فـي لئي شهر ديسمبر الى مارس للقصب الغرس. ولوحظ ان بعض برس برس التز اكيب الور اثية في كل ميعاد زر اعة كان بينها تز امن فى

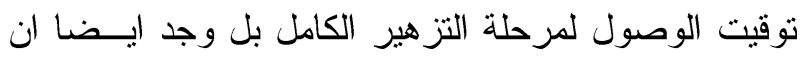

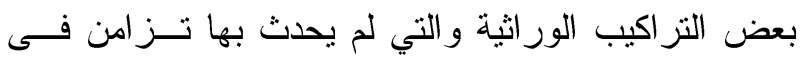

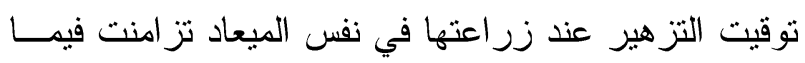

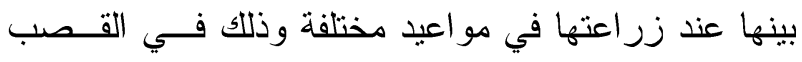
الغرس وهذا بدوره يوضـح انه يمكن القيام بعملية التهجـين

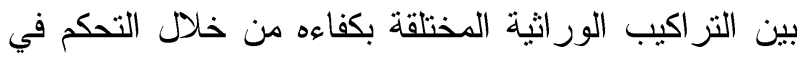

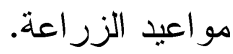

يعتبر النزهير في قصب السكر أمراً ضرورياً فـى اي برنامج تربية ويعتبر التزامن في التزهير بــين التزاكيـبـ الور اثية المختلفة من المتطلبات الهامه لاجر اء التهجينـات المرغوبة. في هذه الدراسة تم اختبار ستة عـشر تركيـاً ور اثياً من قصب السكر مستوردة من بلدان مختلفة للنزهير تحت الظروف الطبيعية بمحطة البحوث الزر اعية بالصبحية

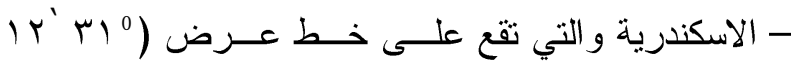

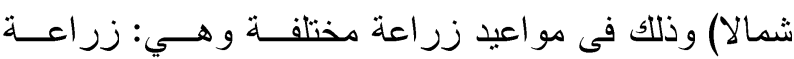

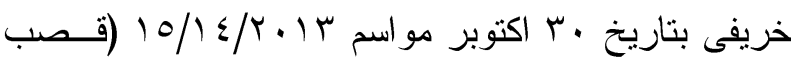

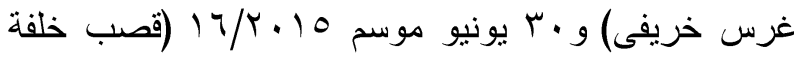

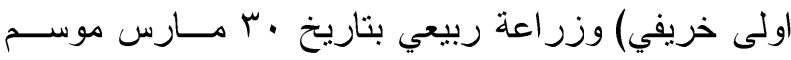

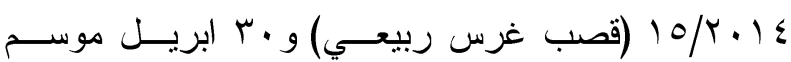
10

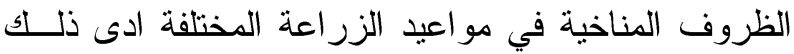
الى الاختلاف في مو اعيد ونسب التزهير بـين التزاكيـبـ

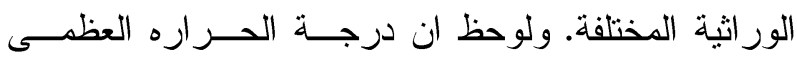

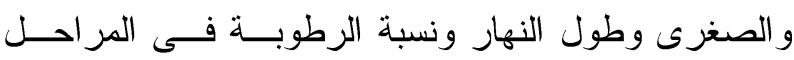
الاولى للاندفاع للتزهير (الاسبوع الاخير من شهر سبتمبر

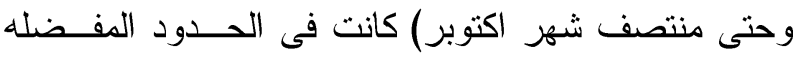
و الملائمه لحدوث التزهير في القصب. ونجد ان التزهير قد حدث في معظم التز اكيب الور اثية المنزرعة تحت الظروف الطبيعية وذللك فى كل من ميعاد الزر اعة الخريفي و الربيعي

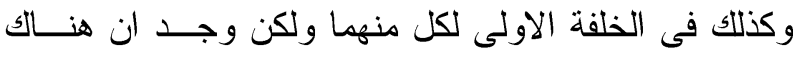

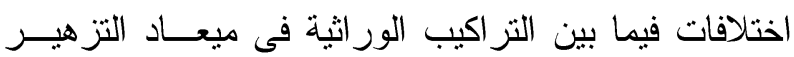
ونسبتة وذللك فيما بين مو اعبد الزر اعة المختلفــة وكــذلك لئك 